\title{
Modeling of 120W Monocrystalline Photovoltaic Module Using MATLAB Simulink
}

\author{
Siti Amely Jumaat, Adhwa Amsyar Syazwan Ab Majid, Mohd Noor Abdullah, \\ Nur Hanis Radzi, Rohaiza Hamdan, Suriana Salimin \\ Green and Sustainable Energy Focus Group, Faculty of Electrical and Electronic Engineering, \\ Universiti Tun Hussein Onn Malaysia, 86400 Parit Raja, Batu Pahat, Johor, Malaysia
}

\section{Article Info \\ Article history: \\ Received Jan 28, 2018 \\ Revised Mar 23, 2018 \\ Accepted Apr 15, 2018}

\section{Keywords:}

Solar

Renewable energy

Photovoltaic (PV)

MATLAB simulink

\begin{abstract}
This project aims to model a solar Photovoltaic (PV) Module using MATLAB Simulink. In Renewable Energy (RE) field, many studies have been carried out to determine the level of efficiency and performance of a specific PV module. Therefore, this research will carry out the modeling of the 120W Monocrystalline Photovoltaic Module by Su-Kam Solar using MATLAB Simulink to determine the efficiency and performance. The input parameters that consists of Solar Irradiance $(\mathrm{G})$ and Temperature $(\mathrm{T})$ data will be collected at location $1.8635^{\circ} \mathrm{N}, 103.1089^{\circ} \mathrm{E}$ which is in Parit Raja, Batu Pahat, Johor. The results are shown in I-V curve and P-V curve and compared with the theory of I-V and P-V curve. Other than that, the PV module have different performance in different value of irradiance and temperature. Lastly, the PV Module is work efficiently and full performance at Standard Test Conditon (STC).
\end{abstract}

Copyright $(9) 2018$ Institute of Advanced Engineering and Science. All rights reserved.

\section{Corresponding Author:}

Siti Amely Jumaat,

Green and Sustainable Energy Focus Group, Faculty of Electrical and Electronic Engineering,

Universiti Tun Hussein Onn Malaysia,

86400 Parit Raja, Batu Pahat, Johor, Malaysia

Email: sitiamely1979@gmail.com

\section{INTRODUCTION}

Nowadays, there are two main concern that have been highlighted by the world regarding the power generation which are shortages of fossil fuels and impact of the generated power towards the environment. Many studies and researches have been carried out by the academicians and one of them is the proposed of the green technology. It consists of many kinds of resources such as solar, wind, hydro and many more. So, by introducing the green technology to the world, it can ensure these matters can be draw out from the world's concern. Solar power is one of the resources used for green technology and it had been widely used in the world. There are two important considerations to use renewable energy which are high efficiency and low carbon emissions. Therefore, solar power that generated from Photovoltaic (PV) module match the considerations as it is considered as most essentials and prerequisite sustainable resource because of the ubiquity, abundance and sustainability of solar radiant energy [1].

Photovoltaic (PV) is a marriage of two words "photo" which is light and "voltaic" which is electricity. PV technology used to describe the systems used to convert solar energy into electricity [2]. In PV system, some problems have been identified such as the initial cost, efficiency and reliability of power generation. Therefore, proper modeling and simulation plays an important role towards the problems of the PV performances [3]. So, the purpose of this research are to develop the Photovoltaic (PV) module using MATLAB Simulink, to determine the performance of 120W Monocrystalline Photovoltaic by Su-Kam Solar and to analyze the efficiency of Photovoltaic (PV) module using MATLAB Simulink. Some researches have been made to make a proper modeling of PV module in MATLAB Simulink. 
This paper [4] have come out with modeling of MSX60 (60W) and MSX64 (64W) PV Module and find out that the PV1-D block is not accurate in high temperature. In paper [5] discussed about KD325GX (325W) and KD330GX (330W) PV module. From the modeling, the PV module only work in full performance in Standard Test Condition (STC). Next, this paper [6] discussed about the steps of PV module modeling in MATLAB Simulink and the input parameter of Solar Irradiance (G) set from 200-600 W/m² and the Temperature (T) varies from $0-60^{\circ} \mathrm{c}$. Lastly, paper [7] discussed on the MSR $245 \mathrm{~W}$ PV Module using PV 1-D equations. The results of I-V and P-V curve is similar with the datasheet that shown the maximum current $\left(I_{m p}\right)$, the maximum voltage $\left(V_{m p}\right)$ and the maximum power $\left(P_{m p}\right)$.

\section{RESEARCH METHOD}

This section will be focusing on the methods to develop the modeling of the solar PV module using MATLAB Simulink. Other than that, the data collection and also the suitable equation used in this research will be discussed. It is divided into meteorological data, the PV data and the equation used for this project.

\subsection{Meteorological Data}

The meteorological data that used in modeling of the solar PV module is obtained from RET Screen software database. This software is used for the free version on academic purpose to manage the energy and have variety of location [8]. There are many inputs data that can be found in the RET Screen software. In this research, the inputs for modeling the solar PV module are the Solar Irradiance $(\mathrm{G})$ and Temperature (T). Solar irradiance and temperature data will be collected at location $1.8635^{\circ} \mathrm{N}, 103.1089^{\circ} \mathrm{E}$ which is in Parit Raja, Batu Pahat, Johor. From the data collected, solar irradiance and temperature for May, June and July 2016 will be used in this project and make as the example for comparison as tabulated in Table 1. It will further discuss on the result and will be analyze.

Table 1. Meteorological Data

\begin{tabular}{cccc}
\hline Month (2016) & $\begin{array}{c}\text { Solar Irradiation } \\
\left(\mathrm{kWh} / \mathrm{m}^{2}\right)\end{array}$ & $\begin{array}{c}\text { Solar Irradiance } \\
\left(\mathrm{kW} / \mathrm{m}^{2}\right)\end{array}$ & Temperature $\left({ }^{\circ} \mathrm{c}\right)$ \\
\hline May & 4.60 & 0.192 & 27.2 \\
June & 4.57 & 0.190 & 26.7 \\
July & 4.49 & 0.187 & 26.2 \\
\hline
\end{tabular}

\subsection{Photovoltaic Module}

The PV characteristic is representing by the I-V curve (current-voltage relationship) and the P-V curve (power-voltage relationship) as shown in Figure 1. The PV will be at full performance during Standard Test Condition (STC) with solar irradiance of $1000 \mathrm{~W} / \mathrm{m}^{2}$ and temperature of $25^{\circ} \mathrm{c}$.

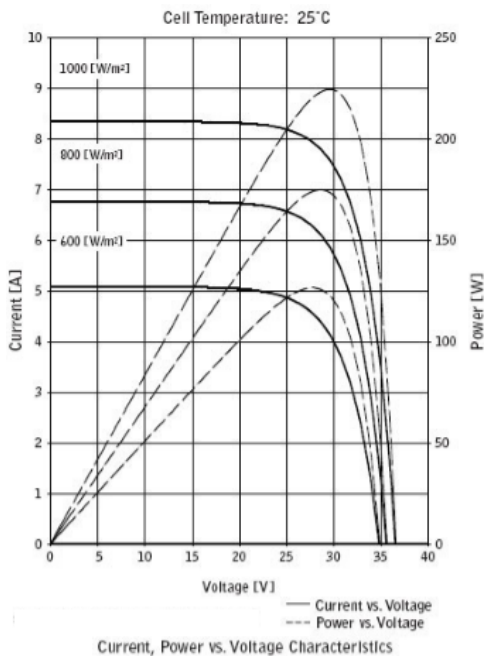

Figure 1. Characteristics of Photovoltaic 
This curve is used to determine the performance of photovoltaic cells, modules and also arrays. The input for this curve is the solar irradiance and cell temperature. Therefore, the output of I-V and P-V curves will be determined. Moreover, the PV cell or module is operating at several voltage and current. Therefore, the maximum power value is determined at knee point of the curve by using the formula of voltage times current. So, it represents the maximum performance of a PV module. Other than the curve pattern will be change in case of different value of solar insolation and same value of temperature or vice versa [9],[10]. In this research, the selected PV module to be analyse is $120 \mathrm{~W}$ Monocrystalline Photovoltaic Su-Kam Solar. The system specifications and ratings at standard test condition are shown in Table 2.

Table 2. Characteristics of 120W Monocrystalline Photovoltaic

\begin{tabular}{cccc}
\hline No & Description & Abbreviation & Data \\
\hline 1 & Nominal Power, PM & $P_{M A X}(\mathrm{~W})$ & 120 \\
2 & Voltage at P PAX & $V_{P M}(\mathrm{~V})$ & 17.7 \\
3 & Current at P PAX & $I_{P M}(\mathrm{~A})$ & 6.8 \\
4 & Open Circuit Voltage & $V_{O C}(\mathrm{~V})$ & 21.4 \\
5 & Short Circuit Voltage & $I_{S C}(\mathrm{~A})$ & 7.2 \\
6 & Module Efficiency & $\%$ & 15.68 \\
7 & Maximum System Voltage & $V_{S Y S}(\mathrm{~V})$ & 600 \\
8 & Module Voltage & $V_{M O D U L E}(\mathrm{~V})$ & 12 \\
9 & Diode Rating & $I_{D I O D E}(\mathrm{~A})$ & 10 \\
\hline
\end{tabular}

\subsection{Circuit and Equation}

The photovoltaic module consists of Photovoltaic Cell that are connected in parallel. This cell is basically a p-n junction that is fabricated and enables to converts the light energy into electricity. The photon will be absorbed by semiconductor after the cell is exposed to the light. Then the electron will flow and creating the electricity. The ideal PV 1 Diode Model is an ideal PV and shown in Figure 2.

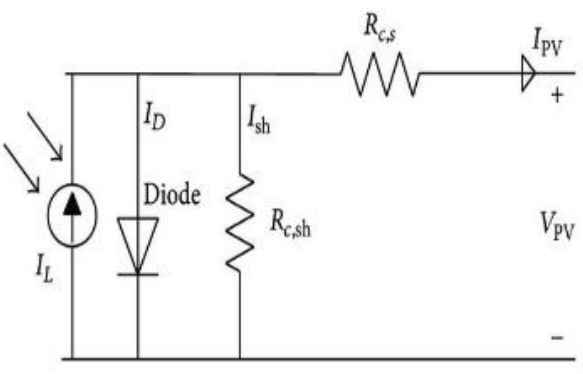

Figure 2. PV 1 Diode Model

There are four equation needed for creating each subsystem and it will get involve along the completion of this project. This equation is used to develop the block diagram in the MATLAB Simulink and create the system for the Photovoltaic (PV) module. Next is the equations involved in this project [7]

$$
\begin{aligned}
& \left.I_{p h}=\left[I_{s c r}+\left(K_{i} *\left(T_{a K}-T_{r K}\right)\right)\right] *\left(\frac{S}{1000}\right)\right] \\
& I_{r s}=I_{s c r} / e^{\left(\frac{q * V o c}{K * N S * A * T r K}\right)-1} \\
& I_{d}=I_{r s} *\left(\frac{T a K}{T r K}\right) 3 * e^{\left[\left(\frac{E g * q}{K * A}\right) *\left(\frac{1}{T r K}-\frac{1}{T a K}\right)\right]} \\
& I_{p v}=N_{p} * I_{p h}-N_{p} * I_{d} *\left\{e^{\left[\left(\left(\frac{q}{N_{S}}\right) * A * K * T_{a K}\right) *\left(V_{p v}+I_{p v} * R_{S}\right)\right]-1}\right\}
\end{aligned}
$$




\section{RESULTS AND ANALYSIS}

This section will discuss on the methods used to develop this project until determined the result and match the purpose of this research. The main purpose of this section is to explain about the steps in modeling the 120W Monocrystalline PV module. The steps of this section are divided into three parts which are the simulation of project, the PV performance analysis and also the PV efficiency analysis.

\subsection{Simulation of Project}

The simulation of project are consists of the modeling of PV module and the modeling of PV system. The PV module is developed from the combination of subsystems. Then, the subsystems are representing the equation from PV 1 Diode model. The design of the PV system can be developed from the PV module. The design of the PV system are consists of the PV Module, Signal Generator, Repeating Sequence and Scope. $\mathrm{I}_{\mathrm{scr}}$ is $7.2 \mathrm{~A}$ and $\mathrm{V}_{\mathrm{oc}}$ is $21.4 \mathrm{~V}$ of the PV Module are set based on the characteristics of $120 \mathrm{~W}$ Monocrystalline Photovoltaic. The results of IV and PV curve are shown in the scope as stated in the diagram. The simulation design is shown in Figure 3.

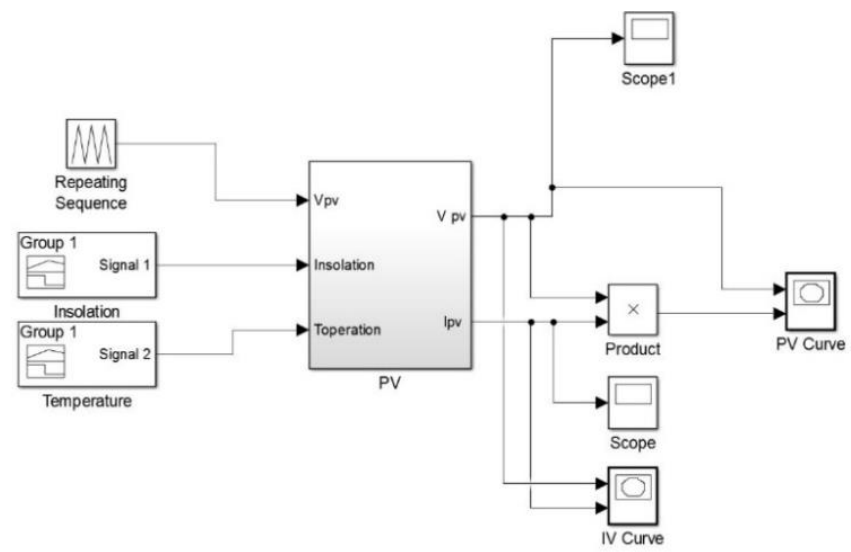

Figure 3. The Complete System of PV

The main subsystem of PV module is developed from the combination of each subsystem. Basically, every subsystem carried out different function based on the design of the block diagrams. The input parameters used in the main subsystem of PV are the solar irradiance and temperature. The output of the main subsystem are I and V curve and give the result of IV and PV curves. The simulation design is shown in Figure 4.

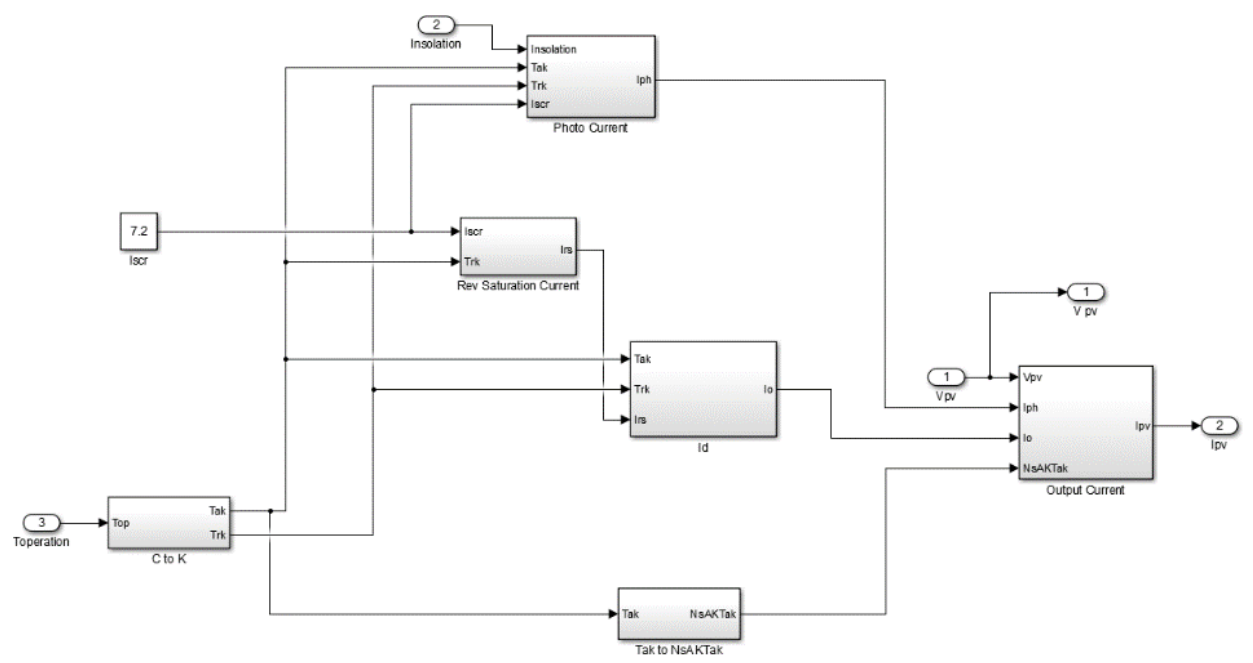

Figure 4. The Main Subsystem of PV 
The subsystem 1 of PV is design to get the PV photo current, which is the light generated current on the PV module in A and referring to Equation (1). The subsystem 2 of PV is design to get the Reverse Saturation Current, Irs in A and referring to Equation (2). The subsystem 3 of PV is design to get the PV Module Saturation Current, $I_{d}$ in A and referring to Equation (3). Lastly, the subsystem 4 of PV is design to get the Module of Output Current, $\mathrm{I}_{\mathrm{pv}}$ in A. This subsystem is referring to Equation (4).

\subsection{PV Performance Analysis}

The PV Performance Analysis of 120W Monocrystalline Photovoltaic is determined by compared the simulation graph with the reference graph. In this part, the result from different temperature and solar irradiance are compared with the reference graph. Therefore, the reference graph of PV performance is shown in Figure 5.
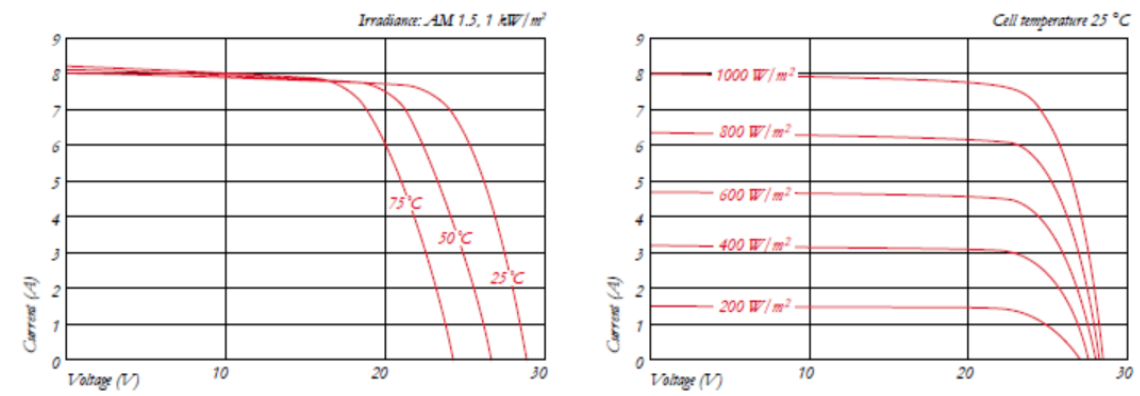

Figure 5. Reference Graph

Firstly, the performance of photovoltaic module can be simulated by comparing the graph of the simulation with the reference in different temperature. In this project, the values of temperature are varying from $15,20,25,30$ and $35^{\circ} \mathrm{c}$ and the solar irradiance is constantly at $1 \mathrm{~kW} / \mathrm{m}^{2}$. Based on the reference graph, during different temperature the current and power is constant until reaching the maximum point. For simulation, the performance of simulated 120W Monocrystalline Photovoltaic also give the same value of current and power. The graphs are shown in Figure 6.

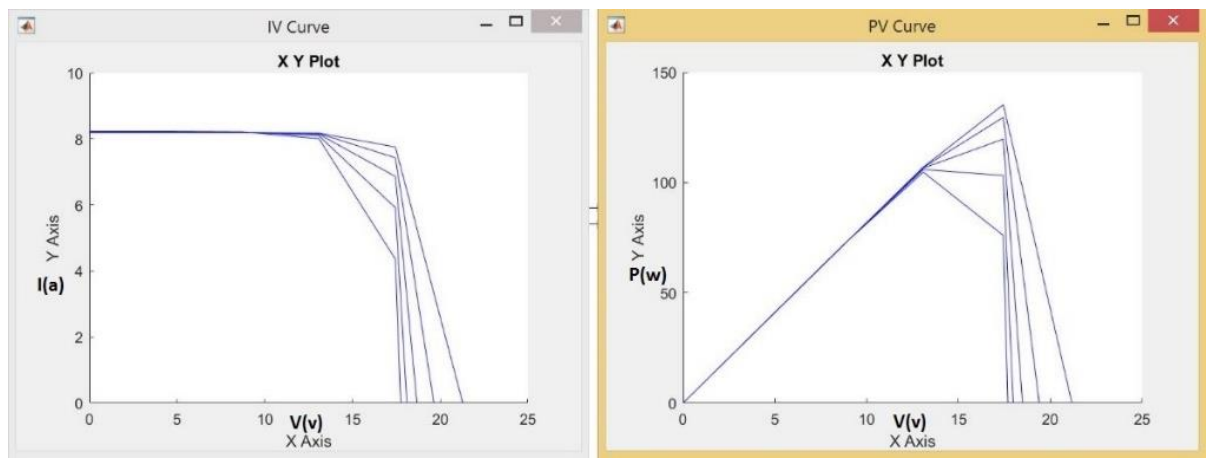

Figure 6. IV and PV Graph in Different Temperature

Secondly, simulation with different values of irradiance also can determine the performance. In this project, the values of irradiance are varying from $0.2,0.4,0.6,0.8$ and $1 \mathrm{~kW} / \mathrm{m}^{2}$ and the temperature is constantly at $25{ }^{\circ} \mathrm{c}$. The different input of irradiance makes the current and power become different. For simulation, the performance of simulated 120W Monocrystalline Photovoltaic also give the different value of current and power. The graphs are shown in Figure 7. 

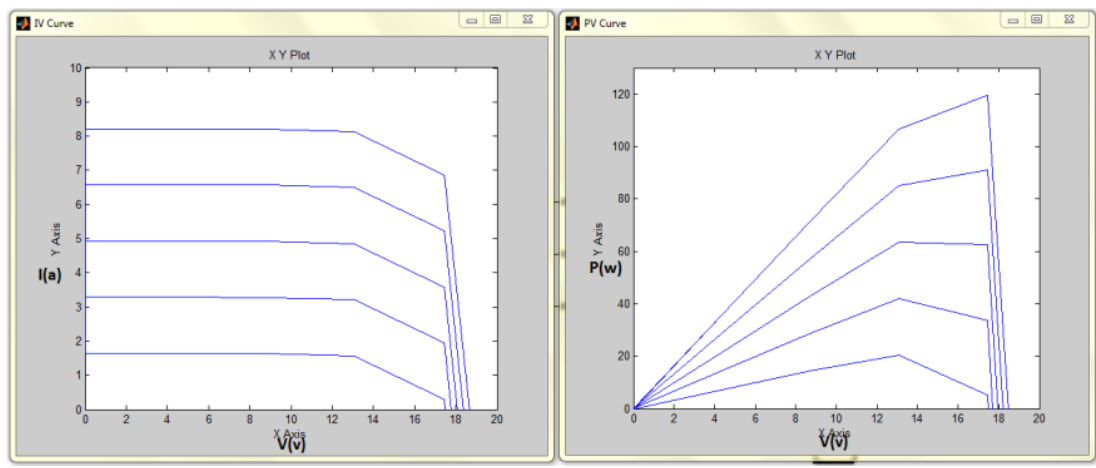

Figure 7. IV and PV Graph in Different Irradiance

\subsection{PV Efficiency Analysis}

PV efficiency analysis is the third objective that need to be achieved in this project. In order to analyze the efficiency of $120 \mathrm{~W}$ Monocrystalline Photovoltaic (PV) module, the results from the three months: May, June and July 2016 are being compared. The parameter for irradiance is set to $0.2,0.4,0.6,0.8$ and $1.0 \mathrm{~kW} / \mathrm{m}^{2}$ and the temperature is constantly set based on the data from RET Screen Expert. The temperature for three months are set differently based on the RET Screen Data. For May $\left(27.2^{\circ} \mathrm{c}\right)$, June $(26.7$ $\left.{ }^{\circ} \mathrm{c}\right)$ and July $\left(26.2^{\circ} \mathrm{c}\right) 2016$.

The IV curve is a representation of Current Vs Voltage Curve. It is a superposition of the IV curve of the solar cell diode in the dark with the light-generated current. The light has the effect of shifting the IV curve down into the fourth quadrant where power can be extracted from the diode. The value of Voltage $(17.7 \mathrm{~V})$ and Current (6.8) in datasheet as reference.

From the simulation, the value of Voltage $\left(V_{m p}\right)$ and Current $\left(I_{m p}\right)$ at Maximum Power Point $(M P P)$ is almost the same with the values in $120 \mathrm{~W}$ Monocrystalline Photovoltaic datasheet. Lastly, the efficiency of the graph only can be determined accurately during Standard Test Condition $\left(1000 \mathrm{~W} / \mathrm{m}^{2}, 25^{\circ} \mathrm{c}\right)$. Other than that, the PV is not working in full performance so it dropped the photovoltaic efficiency level in term of voltage and current. The graphs are shown in Figure 8.

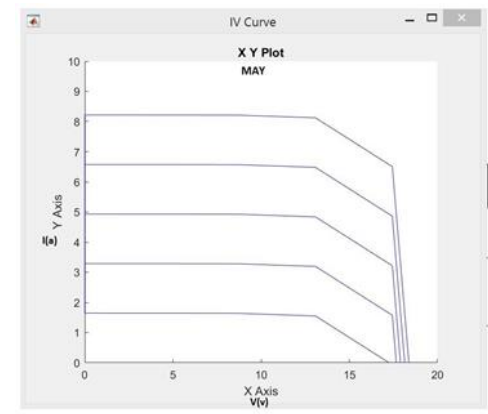

(a)

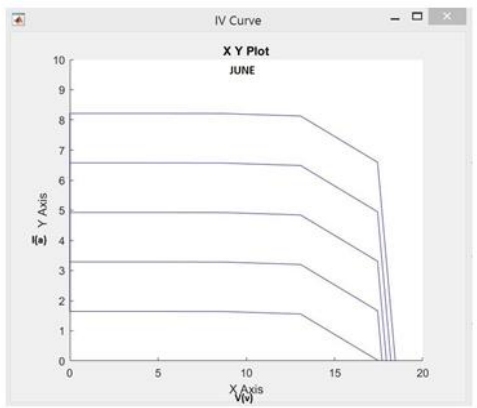

(b)

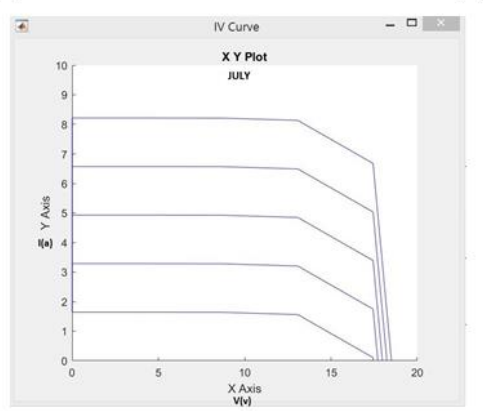

(c)

Figure 8. IV Curves (a) May, (b) June and (c) July 2016 
Next, the PV Curve is a representation of Power vs Voltage for 120W Monocrystalline Photovoltaic Module. The value of Power $(120 \mathrm{~W})$ and Voltage $(17.7 \mathrm{~V})$ is make as reference for this part. Based on the graph, the value of Power $\left(P_{m p}\right)$ and Voltage $\left(V_{m p}\right)$ at Maximum Power Point (MPP) is almost the same with the values in the datasheet. Therefore, the efficiency of the graph only can be determined accurately during Standard Test Condition $\left(1000 \mathrm{~W} / \mathrm{m}^{2}, 25{ }^{\circ} \mathrm{c}\right)$. Other than that, the photovoltaic is not working in full performance so dropped the photovoltaic efficiency level in term of power and voltage. The graphs are shown in Figure 9.

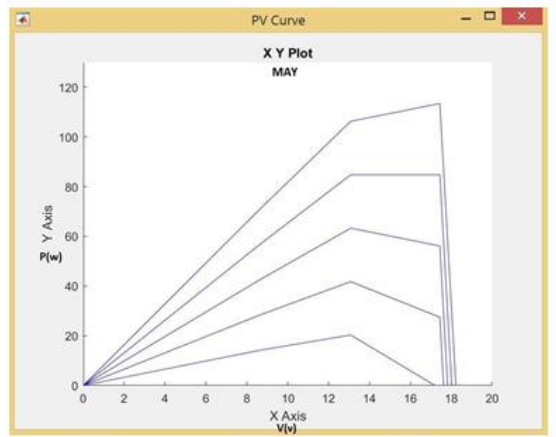

(a)

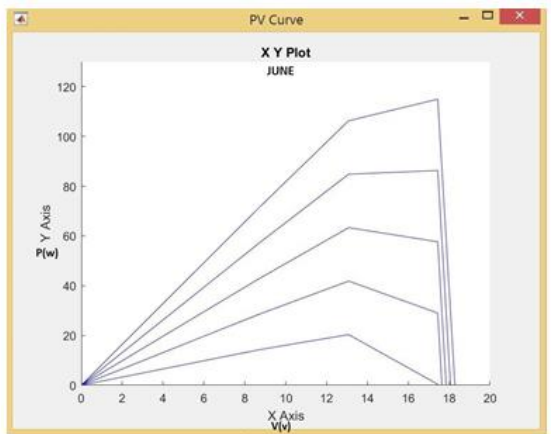

(b)

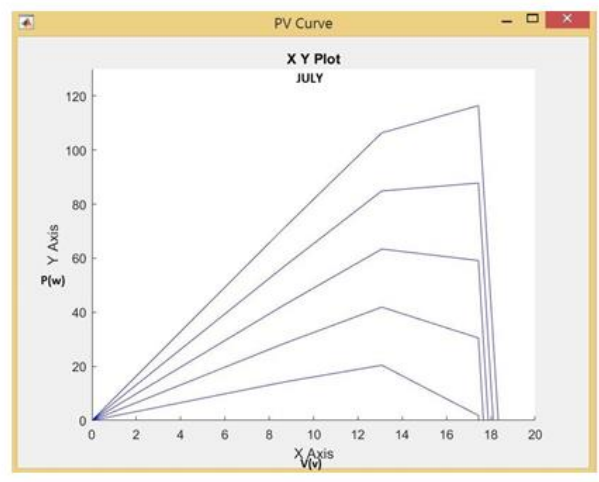

(c)

Figure 9. PV Curves (a) May, (b) June and (c) July 2016

\section{CONCLUSION}

An application of the $120 \mathrm{~W}$ Monocrystalline Photovoltaic using MATLAB Simulink has been presented in this study. As the conclusion, the simulation using MATLAB Simulink get the result almost the same with reference I-V and P-V curve theoretically. The design of PV module has been made based on the datasheet of the $120 \mathrm{~W} \mathrm{Su-Kam} \mathrm{Solar} \mathrm{and} \mathrm{run} \mathrm{the} \mathrm{simulation} \mathrm{without} \mathrm{any} \mathrm{problem.} \mathrm{The} \mathrm{only} \mathrm{problem} \mathrm{occur}$ is the graph is not smooth as the reference graph. Therefore, first purpose is achieved.

Secondly, from the results obtained, a comparison analysis can be made for different temperature and different irradiance with the reference graph. From the observation, it can be concluded that the differences of both input parameter produces a different pattern of I-V and P-V curves. In this project, the curves are following the pattern as the reference graph. So, the second purpose is achieved.

Thirdly, the analysis on the efficiency of the PV Module in three consecutive months which are May, June and July 2016 have been made. But, the graph does not have much differences due to the temperature data from Ret Screen. But, it can be conclude that the graph will achieve a full performance if it is in Standard Test Condition (STC). Then, if the input parameter has a better temperature differences, then the different pattern of I-V and P-V curves can be seen easily. So, the third purpose is achieved.

Next, this project can be done and achieve all the objectives stated for this project. Therefore, it can be said that there is a correlation between the input parameters from meteorological data to predict I-V and PV curve for any PV Module as well as designing the PV module using MATLAB Simulink. 


\section{ACKNOWLEDGEMENTS}

The authors would like to acknowledge the Research Management Center (RMC), Universiti Tun Hussein Onn Malysia (UTHM), Batu Pahat, Johor, Malaysia for the financial support of this search. This research is partly by RMC under the U861 (Tier 1) Grant.

\section{REFERENCES}

[1] H. Tsai, et al., "Development of Generalized Photovoltaic Model Using MATLAB/Simulink," World Congress on Engineering and Computer Science (WCECS). San Francisco, pp. 6, 2008.

[2] K. McDonald eds, "Solar Electricity for Over One Billion People and Two Million Jobs by 2020," Greenpeace International. Report number: 1, 2006.

[3] F. Brihmat and S. Mekhtoub, "PV Cell Temperature / PV Power Output Relationships Homer Methodology Calculation," International Journal of Scientific Research and Engineering Technology, vol/issue: 2(1), 2014.

[4] S. S. Mohammed, "Modeling and Simulation of Photovoltaic Module using MATLAB / Simulink," International Journal of Chemical and Environmental Engineering, vol/issue: 2(5), 2011.

[5] S. V. Vedanayakam, et al., "A Detailed MATLAB Modeling of Photovoltaic Module," International Journal of Industrial Electronics and Electrical Engineering, vol/issue: 4(10), pp. 28-32, 2016.

[6] H. Bellia, "A Detailed Modeling of Photovoltaic Module using MATLAB," NRIAG Journal of Astronomy and Geophysics, vol/issue: 3(1), pp. 53-61, 2014.

[7] N. A. Zainal, "Modelling of Photovoltaic Module using MATLAB Simulink," IOP Conference on Materials Science and Engineering. Pahang, 2016.

[8] S. A. Jumaat and F. Crocker, "Investigate the Photovoltaic (PV) Module Performance using Artificial Neural Network (ANN),” IEEE Conference on Open Systems (ICOS). Langkawi, 2016.

[9] P. Hersch and K. Zweibel, "Basic Photovoltaic Principles and Methods," Antimicrob. Agents Chemother, vol/issue: 58(12), pp. 7250-7, 1982.

[10] I. Characteristics and P. Connections, "Cells, Modules and Arrays," 2012. 